JeMAS 11 (2) (2016) xx-xx
Jitt://journal.unnes.ac.id/nju/index.php/kemas

\title{
ANALISIS SITUASI PERMASALAHAN SAMPAH KOTA YOGYAKARTA DAN KEBIJAKAN PENANGGULANGANNYA
}

\author{
Asti Mulasari ${ }^{\circledR}$, Adi Heru Husodo ${ }^{2}$ Noeng Muhadjir ${ }^{2}$ \\ ${ }^{1}$ Fakultas Kesehatan Masyarakat Universitas Ahmad Dahlan \\ ${ }^{2}$ FK Universitas Gadjah Mada Yogyakarta
}

\begin{tabular}{l} 
Info Artikel \\
\hline Sejarah Artikel: \\
Diterima 24 September 2015 \\
Disetujui 22 Desember 2015 \\
Dipublikasikan Januari 2016 \\
\hline Keywords: \\
Problem; Policy; \\
Management; Waste. \\
\hline DOI \\
http://dx.doi.org/10.15294/ \\
kemas.v11i1.3521 \\
\end{tabular}

\begin{abstract}
Abstrak
Kontak langsung dengan sampah dapat berisiko mengalami gangguan kesehatan. Volume sampah dipengaruhi oleh jumlah penduduk, aktivitas, dan gaya hidup. Pemerintah daerah memberlakukan berbagai kebijakan untuk mengatasi permasalahan sampah sebagai bentuk tanggung jawab pelayanan publik. Tujuan dari penelitian ini adalah untuk mengetahui permasalahan sampah dan upaya penanganan di Kota Yogyakarta. Metode penelitian adalah deskriptif kualitatif. Teknik pengambilan sampel dengan cara purposive sampling. Informan merupakan stakeholder pengelolaan sampah di Yogyakarta. Data diolah dan disajikan dengan metode explanation building. Sampah di TPA Piyungan tertinggi pada Maret 2014 dan terendah pada Juli 2014. Kota Yogyakarta penyumbang sampah terbanyak di TPA Piyungan, kemudian Kabupaten Sleman dan Bantul. Volume sampah tertinggi pada 2012 dan terus menurun sampai tahun 2014. Semua permasalahan ada dari sisi hilir (masyarakat), proses (pengelola sampah) dan hulu (TPA). Setelah semua diidentifikasi, dibuat suatu kebijakan pengelolaan sampah secara optimal dengan melibatkan semua lintas sektoral dan program-program pemberdayaan oleh stakeholder terkait.
\end{abstract}

\section{A SITUATION ANALYSIS OF WASTE PROBLEM IN YOGYAKARTA MUNICIPALITY INDONESIA AND THE POLICY PREVENTION}

\begin{abstract}
Direct contact with the waste can be increasing health problems risk. The volume of waste is affected by population, population activities, and lifestyle. Government enforces many policy in order to address the waste problems. The purpose of this study was to find out the waste problem in the Yogyakarta Municipality and to know the strategy to handling it. Qualiative study was applied in this research. The informant was a delegation of stakeholder regarding waste management, with purposive sampling. Analysis data were performed by using explanantion building using content analysis. The highest number of waste was produced on March 2014 and the lowest on July 2014.. In Yogyakarta municipality, TPA Piyungan gave biggest waste contribution. . The peak of waste volume was in 2012 and tend to decrease until 2014. All the waste problems started from the downstream (community), process (government who manage waste) and upstream (TPA). All problem were identified and government made a policy about manage waste that involved all sectoral empowering program by stakeholder on waste management.
\end{abstract}

(c) 2016 Universitas Negeri Semarang

\footnotetext{
Alamat korespondensi:

Jl. Prof. Dr. Soetomo Janturan Warungboto Yogyakarta

Email : rahmasti_fkmuad@yahoo.com
} 


\section{Pendahuluan}

Sampah mengandung berbagai bahan beracun seperti logam berat, insektisida, dan sebagainya, sehingga manusia yang kontak langsung dengan sampah dapat berisiko mengalami gangguan pencernaan kronik. Oleh karena itu, perlu berhati-hati terhadap sampah yang banyak dan menumpuk terutama pengangkut sampah yang memegang atau mengalami kontak langsung dengan sampah sebaiknya menggunakan alat pelindung diri (APD) (Burhanudin, 2008). Pengelolaan sampah merupakan tanggung jawab pemerintah sebagai salah satu bentuk pelayanan publik, yaitu dengan membuat kebijakan dalam pengelolaan sampah.

Pelayanan publik adalah segala bentuk jasa pelayanan, baik dalam bentuk barang ataupun jasa publik yang pada prinsipnya menjadi tanggung jawab dan dilaksanakan oleh negara untuk mempertahankan dan meningkatkan kualitas kehidupan orang banyak. Pengertian kebijakan adalah keputusan atau tindakan yang mengatur pengelolaan dan pendistribusian sumber daya alam, finansial, dan manusia demi kepentingan umum atau masyarakat (Suharto, 2008). Keberhasilan sistem manajemen yang baik dalam pengelolaan sampah dari pemerintah dan masyarakat dapat terwujud karena adanya organisasi yang bertanggung jawab dengan struktur organisasi yang jelas (Mulasari, 2007). Pemerintah dalam menjalankan fungsi pelayanan publik seringkali mengalami kendala, oleh karena itu dibutuhkan kerja sama semua pihak untuk menyelesaikannya. Kendala bagi penyediaan layanan publik di antaranya adalah infrastruktur, sumber daya, dan kerangka kelembagaan pelayanan publik. Meningkatkan pelayanan publik seringkali merupakan permasalahan manajemen dibandingkan dengan masalah teknis atau masalah keuangan (Galileo, 2012).

Profil Badan Lingkungan Hidup (BLH) Kota Yogyakarta Tahun 2013 menyebutkan bahwa sampah yang terangkut ke tempat pembuangan akhir (TPA) sampah paling banyak adalah dari Kota Yogyakarta (34,89\%), kemudian Sleman (13,17\%), Kulon Progo (7,20\%), Gunung Kidul (5,37\%0, dan terakhir Bantul $(1,91 \%)$. Kota Yogyakarta dipilih sebagai lokasi penelitian karena sampah yang dihasilkan di Kota Yogyakarta merupakan sampah terban- yak yang dibuang ke tempat pembuangan akhir (TPA) sampah Piyungan. Kota Yogyakarta menghasilkan 900 gram per hari per orang. Per hari dalam satu keluarga dengan lima orang anggota keluarga menghasilkan 4.500 gram sampah dan dalam satu tahun menghasilkan $1.620 \mathrm{~kg}$ per hari. BLH Kota Yogyakarta telah melakukan evaluasi bahwa setelah perumahan, transportasi, dan komersial, ternyata sampah menduduki urutan keempat sebagai produsen emisi masyarakat dengan kapasitas 158.692 ton ekuivalen $\mathrm{CO} 2$ atau $\mathrm{CO} 2 \mathrm{e}$.

Anggaran yang dikeluarkan Pemerintah Daerah Kota Yogyakarta cukup besar. Pada tahun 2012 telah ada anggaran sebesar Rp 12 miliar yang dialokasikan untuk pengelolaan sampah, sebesar Rp 2,1 miliar untuk pengelolaan sampah di TPA sampah Piyungan Bantul, sedangkan sisanya digunakan untuk pengangkutan sampah. Sarana prasarana pengolahan sampah di Kota Yogyakarta belum memadai. Tempat pembuangan sementara (TPS) sampah yang berjumlah 120 lokasi tidak sebanding dengan volume sampah yang dihasilkan masyarakat di Kota Yogyakarta. Kendala yang dialami Pemerintah untuk menambah jumlah TPS sampah adalah persoalan teknis, yaitu keterbatasan lahan kosong serta tidak semua warga berkenan untuk dibangun TPS sampah di sekitar lingkungannya karena menimbulkan bau.

Pemerintah Provinsi Daerah Istimewa Yogyakarta (DIY) ikut serta menangani manajemen pengelolaan sampah di Kota Yogyakarta. Sekretariat Bersama Yogyakarta, Sleman, dan Bantul (Sekber Kartamantul) adalah satuan kerja yang bertugas mengawasi pengelolaan sampah di tingkat provinsi untuk bekerja sama dengan BLH di kabupaten/kota. Pengawasan yang dilakukan mulai dari penarikan retribusi, pengumpulan dari sumber untuk dibawa ke TPS sampah, pengangkutan sampah TPS sampah ke TPA sampah Piyungan oleh puluhan truk atau kendaraan pengakut sampah lain yang beroperasi di tiga daerah (Kota Yogyakarta, Sleman, dan Bantul) sampai dengan pengoperasian TPA sampah Piyungan. Hal tersebut menunjukkan manajemen sampah terpadu yang memungkinkan rawan konflik, karena adanya perbedaan kepentingan pada otonomi daerah. Permasalahan yang lain adalah campur 
Tabel 1. Permasalahan Sampah Kota Yogyakarta

\begin{tabular}{|c|c|c|c|}
\hline No & Permasalahan Sampah & Solusi & Sumber/bukti Dokumen \\
\hline 1 & $\begin{array}{l}\text { Belum seluruh wilayah terjangkau } \\
\text { pelayanan sampah }\end{array}$ & $\begin{array}{l}\text { Peningkatan sarana dan prasa- } \\
\text { rana daerah Penganggaran untuk } \\
\text { penambahan infrasturktur }\end{array}$ & $\begin{array}{l}\text { Renstra PUP-ESDM 2009- } \\
2013 \text { Rencana Kinerja Tahu- } \\
\text { nan (RKT) Tahun } 2014 \text { Kota } \\
\text { Yogyakarta }\end{array}$ \\
\hline 2 & Pencemaran air sungai & $\begin{array}{l}\text { Pengembangan kapasitas dan } \\
\text { pemberdayaan untuk mengelola } \\
\text { sampah }\end{array}$ & $\begin{array}{l}\text { Profil BLH Kota Yogyakarta } \\
\text { Tahun } 2013\end{array}$ \\
\hline 3 & $\begin{array}{l}\text { Perilaku masyarakat yang belum baik } \\
\text { dalam mengolah sampah }\end{array}$ & $\begin{array}{l}\text { Pengembangan kapasitas dan } \\
\text { pemberdayaan untuk mengelola } \\
\text { sampah }\end{array}$ & $\begin{array}{l}\text { Profil BLH Kota Yogyakarta } \\
\text { Tahun } 2013\end{array}$ \\
\hline 4 & $\begin{array}{l}\text { Keterbatasan umur teknis TPA } \\
\text { Piyungan }\end{array}$ & $\begin{array}{l}\text { Pengembangan kapasitas dan } \\
\text { pemberdayaan untuk mengelola } \\
\text { sampah }\end{array}$ & $\begin{array}{l}\text { Profil BLH Kota Yogyakarta } \\
\text { Tahun } 2013\end{array}$ \\
\hline 5 & $\begin{array}{l}\text { Keberlanjutan metode pengelolaan } \\
\text { sampah TPA Piyungan }\end{array}$ & $\begin{array}{l}\text { Studi banding ke TPA Bengkala } \\
\text { Kabupaten Buleleng Bali April-Mei } \\
2013\end{array}$ & $\begin{array}{l}\text { Buletin Kartamantul Edisi I } \\
\text { Januari-April } 2013 \\
\text { Dan IV } 2013\end{array}$ \\
\hline 6 & $\begin{array}{l}\text { Keberadaan TPS Ilegal di perbatasan } \\
\text { Kota Yogyakarta }\end{array}$ & $\begin{array}{l}\text { Pendampingan Kartamantul bek- } \\
\text { erjasama dengan LSM Lestari }\end{array}$ & $\begin{array}{l}\text { Buletin Kartamantul Edisi II } \\
\text { Mei-Juni } 2013\end{array}$ \\
\hline 7 & Ilegal dumping sampah & $\begin{array}{l}\text { Pendampingan Kartamantul bek- } \\
\text { erjasama dengan LSM Lestari }\end{array}$ & $\begin{array}{l}\text { Buletin Kartamantul Edisi II } \\
\text { Mei-Juni } 2013\end{array}$ \\
\hline 8 & $\begin{array}{l}\text { Amanat UU No. } 18 \text { Tahun } 2008 \\
\text { menerapkan sanitary landfill ataupun } \\
\text { teknologi lain yang berbiaya besar }\end{array}$ & $\begin{array}{l}\text { Pemerintah DIY berperan serta } \\
\text { dalam pengelolaan TPA Piyungan }\end{array}$ & $\begin{array}{l}\text { Bulatin Kartamantul Edisi } \\
\text { IV } 2013\end{array}$ \\
\hline
\end{tabular}

Sumber : Data Primer

tangan pemerintah provinsi ternyata tidak begitu saja menyelesaikan berbagai permasalahan persampahan di DIY, seperti penegakan regulasi, pendanaan, dan pemberdayaan masyarakat. Berdasarkan hal tersebut, penelitian yang dilakukan di Kota Yogyakarta ini bermaksud untuk menganalisis permasalahan persampahan di Kota Yogyakarta dan segala upaya, baik kebijakan dan program, untuk mengatasi permasalahan tersebut.

\section{Metode}

Metode yang digunakan dalam penelitian ini adalah analisis kualitatif. Studi kualitatif digunakan untuk mengungkapkan fenomena permasalahan sampah dan pengelolaan sampah di Kota Yogyakarta. Peneliti berinteraksi dengan subjek atau informan dengan cara observasi, partisipasi observasi, dan wawancara, dilakukan pula studi dokumen tentang persampahan yang terdokumentasi pada stakeholder pengelolaan sampah Kota Yogyakarta. Teknik pengambilan sampel menggunakan purposive sampling. Data dianalisis dengan metode explanation building yaitu menyusun kepingan-kepingan informasi dari sumber dan subjek penelitian untuk dijadikan suatu kesimpulan yang mengerucut. Semua sumber diperiksa dan dievaluasi bersama sehingga merupakan gabungan informasi dari berbagai bukti dokumen, hasil observasi, dan hasil wawancara, lalu kemudian ditranskrip (Yin, 2014). Penelitian dilakukan di Kota Yogyakarta pada tahun 2014. Subjek dan objek penelitian berasal dari BLH Kota Yogyakarta, Sekber Kartamantul DIY, Dinas Pekerjaan Umum Perumahan Dan Energi Sumber Daya Mineral (PUP-ESDM) DIY, Dinas Kesehatan Kota Yogyakarta, Dinas Kesehatan Provinsi DIY dan TPA Piyungan. Dalam penelitian ini dilakukan metode triangulasi sumber dan data untuk mengantisipasi adanya kelemahan pada data yang diperoleh.

\section{Hasil dan Pembahasan}

Permasalahan sampah diidentifikasi dari stakeholder, dan akan melihat tren jumlah timbulan sampah di TPA Piyungan. Hasil tersebut dapat dilihat pada Tabel 1. 


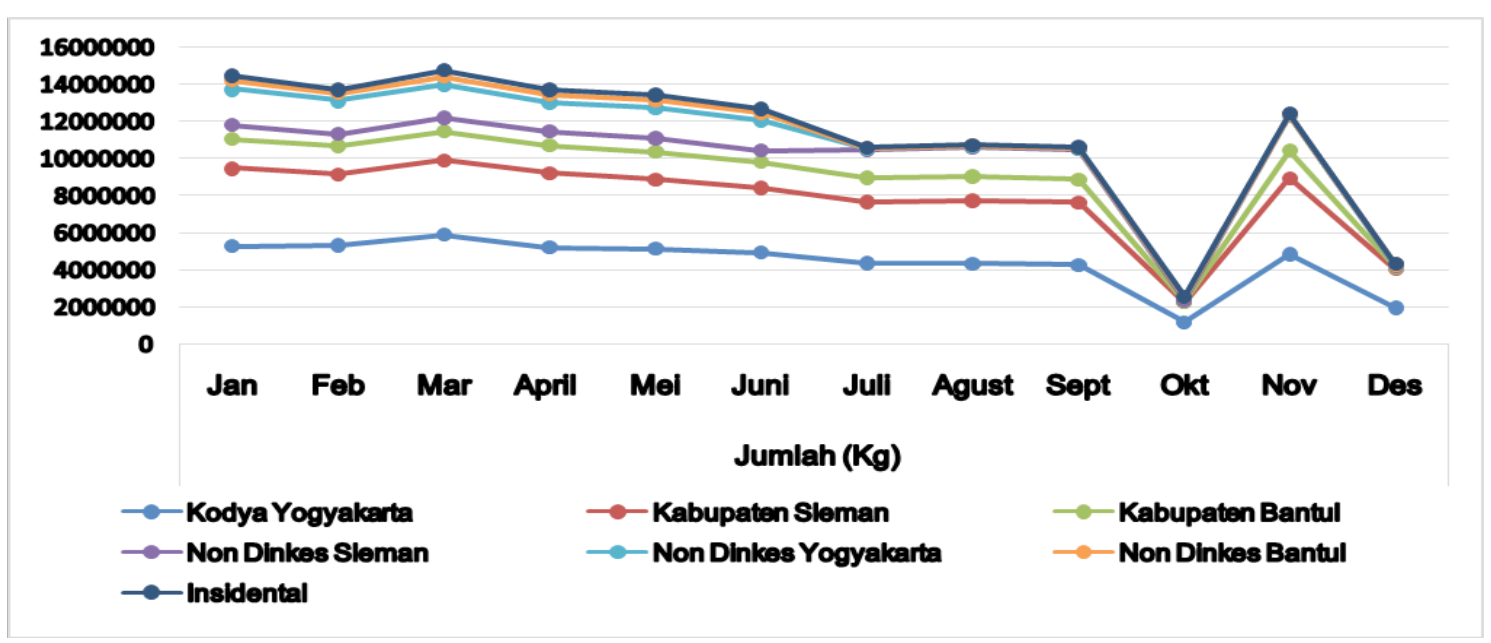

Gambar 1. Timbulan sampah di Daerah Istimewa Yogyakarta (DIY) termasuk jumlah timbulan sampah di Kota Yogyakarta yang dibuang ke TPA Piyungan Tahun 2014

Dari Tabel 1 dapat dilihat bahwa permasalahan sampah di Kota Yogyakarta terkait dengan masalah jangkauan pelayanan, dampak dari perilaku pembuangan sampah yang tidak baik, dan masalah teknis pengelolaan sampah di TPA Piyungan.

Dari Gambar 1 terlihat penurunan yang signifikan pada bulan Oktober dan Desember 2014. Kerusakan tersebut tepatnya terjadi pada tanggal 01 Oktober 2014 - 23 Oktober 2014 serta pada tanggal 15 Desember 2014 - 31 Desember 2014. Hal itu karena terjadi kerusakan teknis jembatan timbang dan perhitungan dilakukan manual, tidak dapat mencatat secara akurat jumlah sampah yang masuk ke TPA Piyungan. Kerusakan jembatan timbang sering terjadi pada setiap tahunnya, misalnya pada tahun 2009, 2009, dan 2010.

Dari Tabel 1 dapat dilihat bahwa permasalahan sampah di Kota Yogyakarta terkait dengan masalah jangkauan pelayanan, dampak dari perilaku pembuangan sampah yang tidak baik, dan masalah teknis pengelolaan sampah di TPA Piyungan. Permasalahan persampahan Kota Yogyakarta dapat dipandang dari tiga sudut pandang yaitu permasalahan dari hilir: penimbul sampah (masyarakat), permasalahan dari proses: organisasi pengelola sampah Kota Yogyakarta (BLH Kota Yogyakarta), dan permasalahan di hulu : pada pengelola sampah akhir (TPA Piyungan).

Pada bagian hilir, permasalahan yang muncul dari masyarakat penimbul sampah adalah kurangya kesadaran masyarakat dalam mensikapi dan mengelola sampah. Masyarakat masih banyak yang membuang sampah sembarangan di sungai. Bahkan ketika sudah disediakan tempat pembuangan sampah sememtara (TPSS) di lingkungannya, masyarakat masih tidak tertib dalam waktu ataupun tempat membuang sampahnya. Konsep 3R (reuse, replace, recycle) tidak diterapkan dengan baik dan perilaku membuang sampah sembarangan masih tinggi.

Permasalah di bagian hilir karena kurangnya kesadaran masyarakat. Perilaku yang tidak baik sering kali disebabkan karena tingkat pengetahuan dan sikap yang kurang baik. Hal tersebut sejalan dengan penelitian Mulasari (2014) yang menyebutkan bahwa banyaknya TPS ilegal kemunginan disebabkan karena pengetahuan dan sikap masyarakat tentang lingkungan yang tidak baik. Pengetahuan dan sikap yang tidak baik tersebut menyebabkan perilaku membuang sampah yang tidak baik pula.

Pada bagian proses, pelayanan publik bidang persampahan di Kota Yogyakarta dilakukan oleh BLH Kota Yogyakarta. Cakupan pelayanan persampahan di Kota Yogyakarta baru mencapai 85\%. Hal tersebut disebabkan karena keterbatasan sumber daya dan anggaran. Permasalahan tersebut terus diupayakan untuk diatasi. Tindakan yang dilakukan dengan terus meningkatan kualitas dan kuantitas saranaprasarana termasuk di dalamnya infrastruktur. 
Selain itu, direncanakan pula program pemberdayaan masyarakat untuk membantu pengelolaan sampah dari sumber penimbulnya. Hal tersebut dinyatakan dengan tegas oleh informan dapat terlihat pula dari perencanaan program yang dilakukan oleh BLH Kota Yogyakarta.

Pada bagian hulu, pengelolaan TPA Piyungan dirasa stakeholder belum dapat maksimal, baik dari sistem atau teknologi yang diterapkan, seperti contoh yang dikemukakan di atas bahwa sering terjadi pula kerusakan sarana prasarana yang ada di TPA. TPA Piyungan pengelolaannya dilakukan dari sharing dana antara Kabupaten Bantul. Sleman, dan Kota Yogyakarta. Upaya perbaikan telah dilakukan dan diinisiasi dengan kerjasama tiga kabupaten/kota dengan fasilitator Sekber Kartamantul walaupun secara bertahap karena keterbatasan teknis dan anggaran. Pemerintah daerah seringkali memiliki permasalahan pengelolaan sampah yaitu terkait dengan permasalahan teknik, anggaran yang terbatas, pemenuhan sarana prasarana yang masih kurang, serta permasalahan pemberdayaan masyarakat (Suyanto, 2014).

Permasalahan yang dihadapi oleh BLH

Kota Yogyakarta terkait persampahan ditemukan di daerah lain seperti di Kabupaten Bengkulu Selatan. Dinas Kebersihan Pertamanan dan Tata Kota Kabupaten Bengkulu selatan memiliki permasalahan dalam usaha optimal- isasi pengelolaan sampah di daerah dan TPA. Sarana prasarana yang belum merata di seluruh wilayah dan sumber daya manusia yang belum terpenuhi menjadi permasalahan utama selain kurangnya kesadaran masyarakat untuk membuang sampah pada tempatnya dan mengolah sampah (Kosmanto, 2012).

Di Zimbabwe, permasalahan dan keterbatasan pengelolaan sampah juga dihadapi oleh Departemen Pengelola Limbah di daerah tersebut. Pertambahan penduduk meningkatkan jumlah sampah, masyarakat masih membuang sampah sembarangan, terjadi kekurangan infrastruktur dan sarana prasarana pengelolaan sampah (Chikobnu, 2011). Di India permasalahan pengelolaan sampah perkotaan disebabkan karena anggaran, sarana-prasarana, perencanaan dan data operasional, dan kepemimpinan (Sharholy, 2008).

Permasalahan persampahan juga terjadi di Kano Metropolis Nigeria. Kota ini memiliki permasalahan terkait kebijakan, anggaran, saran dan prasarana, serta teknis pengelolaan sampah (Butu, 2014). Ibadan, Nigeria, permasalahan sampah disebabkan karena sikap warganya yang tidak sadar lingkungan, kurangnya sumber daya manusia dan sarana prasarana pengelolaan, kurangnya perencanaan tata kota dan minimnya anggaran (Fafioye, 2013). Lagos Municipality, Negeria, memiliki permasalahan tentang perilaku membuang

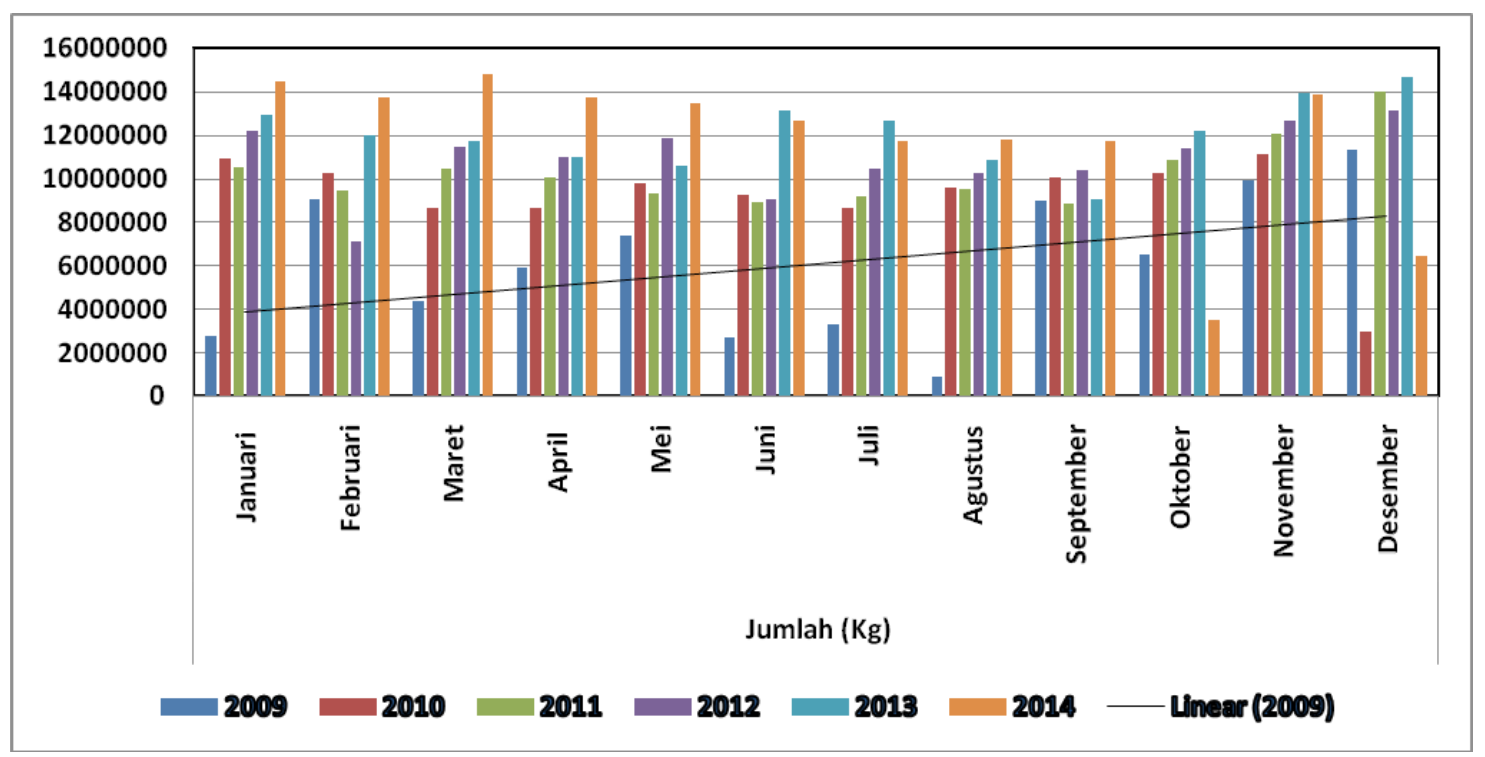

Gambar 2. Volume sampah perbulan per tahun di TPA Piyungan (data 2009-2014) 


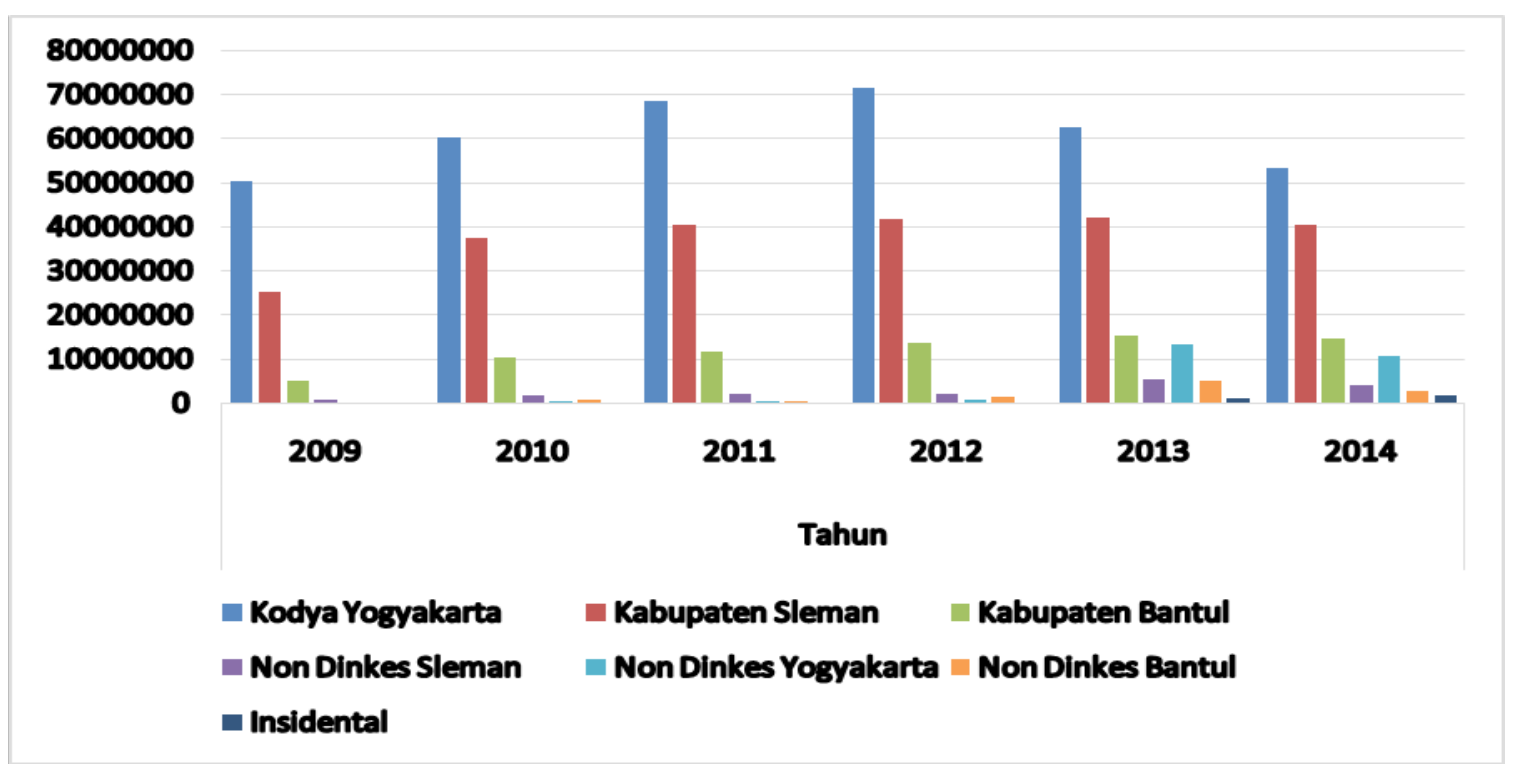

Gambar 3. Volume sampah dari sumber penghasil sampah dari tahun 2009-2014

sampah sembarangan, TPA ilegal, dan penumpukan sampah di kota (Ojo, 2014).

Gambar 2 menunjukkan bahwa dari tahun ke tahun, sejak tahun 2009 sampai 2014, volume sampah yang diangkut ke TPA Piyungan mengalami peningkatan (ditunjukkan dari garis linier trendline). Sampah pada tahun 2014 merupakan sampah terbanyak dibanding tahun sebelumnya. Penyimpangan data terjadi pada Oktober dan Desember 2014 karena terjadi kerusakan server jembatan timbang di TPA Piyungan.

Gambar 3 menunjukkan bahwa Kota Yogyakarta pada setiap tahunnya merupakan penyumbang sampah terbesar yang diangkut ke TPA Piyungan, diikuti oleh Kabupaten Sleman dan Bantul. Volume sampah tertinggi pada tahun 2012 dan terus menurun sampai tahun 2014.

Hasil penelitian menunjukkan volume sampah terbanyak dihasilkan oleh Kota Yogyakarta diikuti oleh Kabupaten Sleman, dan Bantul. Pada akhir tahun kemungkinan besar sampah di DIY meningkat karena merupakan musim liburan dan banyak wisatawan yang berkunjung dari daerah lain ke DIY. Seperti halnya yang terjadi di Kota Yogyakarta, daerah perkotaan hampir selalu memiliki masalah persampahan yang sama. Peningkatan penduduk, migrasi, dan perkembangan industri di suatu daerah meningkatkan produksi sampah. Kondisi tersebut juga terjadi di banyak daerah atau negara, seperti di Nigeria. Perkembangan industri dan ledakan populasi menyebabkan adanya migrasi ke daerah perkotaan dan mengakibatkan peningkatan jumlah sampah secara signifikan (Butu, 2014).

Di Kota Dhaka, Bangladesh, kenaikan volume sampah dipengaruhi oleh bulan dan musim. Volume sampah di negara tersebut meningkat ketika musim hujan dan ketika musim buah (Hai, 2005). Penelitian di Missouri Colombia menyebutkan bahwa volume sampah di sana dipengaruhi oleh musim dan kondisi geografi (Zeng, 2005).

Pengelolaan sampah di Kota Yogyakarta sebagai solusi permasalahan sampah telah dilakukan oleh BLH Yogyakarta dan Sekber Kartamantul DIY. Pengelolaan sampah dilakukan dengan membuat beberapa kebijakan dengan dilandasi peraturan perundangan. Hal tersebut membuktikan keseriusan pemerintah dalam mengatasi permasalahan sampah perkotaan.

Pengelolaan sampah yang diatur dalam berbagai peraturan perundangan tersebut pada Tabel 2 menunjukkan legalitas dan kewajiban yang mengikat untuk melaksanakan pengelolaan sesuai yang diamanatkan oleh barbagai peraturan perundangan tersebut. Hal itu dapat berarti pula bahwa pengelolaan sampah di Kota Yogyakarta merupakan hal yang dianggap penting dan strategis harus dilakukan. Permasalahan sampah Kota Yogyakarta menjadi tanggung jawab bersama antara beberapa instansi.

Dari Tabel 3 telah terlihat berbagai ben- 
Tabel 2. Dasar Kebijakan Pengelolaan Sampah Kota Yogyakarta

\begin{tabular}{|c|c|c|}
\hline No & Perundangan & Jenis Perundangan \\
\hline 1 & Undang-undang RI & $\begin{array}{l}\text { Undang-Undang RI No. } 32 \text { Tahun } 2009 \text { Tentang Perlindungan dan Pengelolaan } \\
\text { Lingkungan Hidup }\end{array}$ \\
\hline \multirow[b]{2}{*}{2} & \multirow{3}{*}{ Peraturan Menteri RI } & Undang-undang RI No. 18 Tahun 2008 Tentang Pengelolaan Sampah \\
\hline & & $\begin{array}{l}\text { Peraturan Menteri Negara Lingkungan Hidup RI No. } 13 \text { Tahun } 2012 \text { Tentang } \\
\text { Pedman Pelaksanaan Reduce, Reuse, dan Recycle Melalui Bank Sampah. }\end{array}$ \\
\hline \multirow{3}{*}{3} & & Permendagri No. 33 Tahun 2010 Tentang Pedoman Pengelolaan Sampah \\
\hline & \multirow[t]{2}{*}{ Peraturan Daerah DIY } & $\begin{array}{l}\text { Perda Daerah Istimewa Yogyakarta No. } 3 \text { Tahun } 2013 \text { Tentang Pengelolaan } \\
\text { Sampah Rumah Tangga Dan Sampah Sejenis Sampah Rumah Tangga }\end{array}$ \\
\hline & & $\begin{array}{l}\text { Peraturan Gubernur Daerah Istimewa Yogyakarta No. } 21 \text { Tahun } 2014 \text { Tentang } \\
\text { Pedoman penanganan Sampah, Perizinan Usaha Pengelolaan Sampah, Dan } \\
\text { Kompensasi Lingkungan }\end{array}$ \\
\hline \multirow[t]{5}{*}{4} & \multirow{5}{*}{$\begin{array}{l}\text { Peraturan Daerah Kota } \\
\text { Yogyakarta }\end{array}$} & Perda Kota Yogyakarta No. 18 Tahun 2002 Tentang Pengelolaan Kebersihan. \\
\hline & & Perda Kota Yogyakarta No. 21 Tahun 2002 Tentang Retribusi Kebersihan. \\
\hline & & Perda Kota Yogyakarta No. 10 Tahun 2012 Tentang Pengelolaan Sampah. \\
\hline & & $\begin{array}{l}\text { Peraturan Walikota Yogyakarta No. } 36 \text { Tahun } 2012 \text { Tentang Petunjuk Teknis Cara } \\
\text { Pemungutan Retribusi Jasa Umum Jenis Retribusi Pelayanan Persampahan/Ke- } \\
\text { bersihan }\end{array}$ \\
\hline & & $\begin{array}{l}\text { Peraturan Walikota Yogyakarta No. } 60 \text { Tahun } 2013 \text { Tentang Pentunjuk Pelaksan- } \\
\text { aan Pemberian dan Pemanfaatan Insentif Pemungutan Retribusi Pelayanan Per- } \\
\text { sampahan/Kebersihan. }\end{array}$ \\
\hline \multirow[t]{2}{*}{5} & \multirow[t]{2}{*}{$\begin{array}{l}\text { Keputusan Bersama } \\
\text { Bantul, Sleman, dan Yo- } \\
\text { gyakarta }\end{array}$} & $\begin{array}{l}\text { Keputusan Bersama Bupati Bantul, Bupati Sleman, dan Walikota Yogyakarta No- } \\
\text { mor: 152a Tahun 2004, 02/SKB.KDH/A/2004, } 03 \text { Tahun } 2001 \text { tentang Kerjasama } \\
\text { Pengelolaan Prasarana dan Sarana Perkotaan antara Kab. Bantul, Kab. Sleman } \\
\text { dan Kota Yogyakarta }\end{array}$ \\
\hline & & $\begin{array}{l}\text { Perjanjian Kerjasama Antara Pemerintah Kota Yogyakarta, Pemerintah Kabu- } \\
\text { paten Sleman dan Pemerintah Kabupaten Bantul tentang Pengelolaan Tempat } \\
\text { Pengolahan Sampah Terpadu (TPST) Di Piyungan Kabupaten Bantul Nomor : } \\
\text { 01/Perj.YK/2011, 02/PK.KDH/A/2011, 03/Perj/Bt/2011 }\end{array}$ \\
\hline
\end{tabular}

Sumber : Sistem Jaringan Dokumentasi dan Informasi Bagian Hukum Pemerintah Kota Yogyakarta (2014) tuk tanggung jawab dalam mengelola sampah tu Sub Bidang Pengangkutan dan Sub Bidang yang kemungkinan telah dilakukan sesuai ka- Pembersihan. Pengelolaan sampah dilaksanapasitas masing-masing. Penelitian menemukan kan berdasarkan peraturan perundangan dan tidak didapatkan adanya kerja sama atau koor- kebijakan anggaran yang telah disusun oleh dinasi lintas sektoral antara pelaksana program DPRD Kota Yogyakarta. Pengelolaan sampah teknis dan program kesehatan dalam bidang di Kota Yogyakarta dimulai dari pengumpulan pengelolaan sampah. Padahal seperti diketahui di TPSS, peyimpanan sementara, pengangkubahwa permasalahan sampah dan pengelolaan- tan, dan pengolahan di TPA Piyungan. Khusus nya erat kaitannya dengan permasalahan kes- untuk pengolahan di TPA Piyungan, dilakukan ehatan masyarakat.

Kerja sama lintas sektoral pengelolaan sampah yang ada di Kota Yogyakarta adalah kerja sama antara PPEJ Regional Jawa, DPUPESDM DIY, Sekber Kartamantul, dan BLH Kota Yogyakarta. Kerja sama lintas sektoral yang dilakukan untuk melakukan pengelolaan sampah perkotaan dan operasional TPA Piyungan.

Dari Tabel 4 dapat diketahui bahwa hasil kerja sama lintas sektoral baru terkait teknis pengelolaan sampah. Belum diketemukan bukti kerja sama antara bidang kesehatan (Dinas Kesehatan dengan Badan Lingkungan Hidup Kota Yogyakarta).

Manajemen pengelolaan sampah di Kota Yogyakarta dilakukan oleh BLH Kota Yogyakarta yang dibagi menjadi dua sub bidang yaisharing sumber daya karena sampah yang diangkut berasal dari tiga daerah kabupaten/kota yaitu Bantul, Sleman, dan Kota Yogyakarta.

Konsep pengelolaan sampah perkotaan yang dilakukan di Kota Yogyakarta sesuai konsep pengelolaan sampah oleh pemerintah daerah yang dikemukakan oleh Galileo. Respon Pemerintah Daerah dalam pengelolaan sampah-sampah yang dihasilkan dari berbagai aktivitas manusia, dapat dikelompokan menjadi enam elemen sebagai upaya pengelolaan sampah daerah, yakni: Pertama, pengendalian bangkitan (control of generation). Kedua, penyimpanan (storage). Ketiga, pengumpulan (collection). Keempat, pemindahan dan pengangkutan (transfer and transport). Kelima, pemrosesan (processing), dan keenam, yaitu 
Tabel 3. Pelaksanaan Tanggung Jawab Permasalahan Sampah di Kota Yogyakarta

\begin{tabular}{|c|c|c|c|}
\hline No & Instansi & Bentuk tanggung jawab & Dokumen \\
\hline $\mathbf{1}$ & $\begin{array}{l}\text { BLH Provinsi } \\
\text { DIY }\end{array}$ & $\begin{array}{l}\text { Program Pengembangan Kinerja Pengelolaan Per- } \\
\text { sampahan dengan kegiatan: } \\
\text { Pengembangan Teknologi Pengelolaan Persampahan } \\
\text { Peningkatan Peran serta masyarakat dalam pengelo- } \\
\text { laan persampahan }\end{array}$ & $\begin{array}{l}\text { Laporan Tahunan BLH DIY } \\
2013\end{array}$ \\
\hline 2 & $\begin{array}{l}\text { BLH Kota Yogya- } \\
\text { karta }\end{array}$ & $\begin{array}{l}\text { Program BLH Kota Yogyakarta } \\
\text { Pelatihan pengelolaan Sampah } \\
\text { Pendampingan pengelolaan sampah mandiri } \\
\text { Pameran produk daur ulang sampah } \\
\text { Sosialisasi pengelolaan sampah mandiri } \\
\text { Layanan kebersihan kota } \\
\text { Penanganan 3R di rumah tangga, sekolah, kator, dan } \\
\text { fasilitas umum }\end{array}$ & $\begin{array}{l}\text { Profil BLH Kota Yogyakarta } \\
2013\end{array}$ \\
\hline \multirow[t]{2}{*}{3} & $\begin{array}{l}\text { Dinas Pekerjaan } \\
\text { Umum, Peruma- } \\
\text { han Dan Energi } \\
\text { Sumber Daya } \\
\text { Mineral (PUP- } \\
\text { ESDM) }\end{array}$ & $\begin{array}{l}\text { Meningkatkan kualitas dan kuantitas prasaranan dan } \\
\text { sarana daerah dalam upaya meningkatkan pelayanan } \\
\text { publik dengan memperhatikan kelestarian lingkun- } \\
\text { gan, dan perencanaan yang berkualitas dengan salah } \\
\text { satu strategi : Peningkatan kesediaan infrastruktur } \\
\text { persampahan dengan kegiatan: } \\
\text { Koordinasi pengelolaan persampahan } \\
\text { Penyusunan NSPK Persampahan }\end{array}$ & $\begin{array}{l}\text { LAKIP DPUP-ESDM Tahun } \\
2013\end{array}$ \\
\hline & & $\begin{array}{l}\text { Program Pegelolaan Persampahan. Kegiatan : } \\
\text { Pembangunan prasarana dan sarana persampahan } \\
\text { Pengelolaan TPA Regional }\end{array}$ & $\begin{array}{l}\text { Rencana Kerja Tahun } 2015 \\
\text { DPUP-ESDM }\end{array}$ \\
\hline \multirow[t]{2}{*}{4} & $\begin{array}{l}\text { Sekertariat bersa- } \\
\text { ma Kartamantul }\end{array}$ & $\begin{array}{l}\text { Kerjasama Pengelolaan Sarana dan prasarana TPA } \\
\text { Piyungan dan penanganan sampah ilegal di daerah } \\
\text { perbatasan Kota Yogyakarta, Sleman, dan Bantul } \\
\text { (fasilitator, Koordinator, dan mediator) }\end{array}$ & $\begin{array}{l}\text { Tanggung Jawab dan We- } \\
\text { wenang Sekber Kartamantul } \\
\text { 2012-2014 }\end{array}$ \\
\hline & & $\begin{array}{l}\text { Forum fasilitasi, perencana dan mediasi untuk me- } \\
\text { mudahkan koordinasi antar tiga daerah dalam me- } \\
\text { nentukan penyediaan pelayan yang terpilih. Pelay- } \\
\text { anan terpilih mencakup } 6 \text { (enam), yaitu: pengelolaan } \\
\text { sampah, pengelolaan limbah, penyediaan air bersih, } \\
\text { saluran pembuangan, jalan dan transportasi }\end{array}$ & $\begin{array}{l}\text { Surat keputusan bersama Bu- } \\
\text { pati Bantul, Bupati Sleman } \\
\text { dan Walikota Yogyakarta No } \\
18 \text { tahun } 2001 \text { Tentang Pem- } \\
\text { bentukan Sekertariat Bersama } \\
\text { Kartamantul. }\end{array}$ \\
\hline 5 & $\begin{array}{l}\text { Dinas Kesehatan } \\
\text { Kota Yogyakarta }\end{array}$ & $\begin{array}{l}\text { Promosi Kesehatan : } 17 \text { Pesan Utama Perilaku Hidup } \\
\text { Bersih dan Sehat }\end{array}$ & $\begin{array}{l}\text { Materi Promosi Kesehatan Di- } \\
\text { nas Kesehatan Kota Yogyakarta } \\
\text { (http://kesehatan.jogjakota. } \\
\text { co.id/?exec=viewprokes\&id=1) }\end{array}$ \\
\hline 6 & $\begin{array}{l}\text { PPEJ Regional } \\
\text { Jawa }\end{array}$ & $\begin{array}{l}\text { Sasaran organisasi : Meningkatnya pengelolaan ba- } \\
\text { han B3 dan sampah }\end{array}$ & $\begin{array}{l}\text { Tujuan dan Sasaran Pusat Pen- } \\
\text { gelolaan Ekoregion Jawa Ke- } \\
\text { mentrian Lingkungan Hidup } \\
\text { (http://ppejawa.com/8_tujuan. } \\
\text { html) }\end{array}$ \\
\hline
\end{tabular}

Sumber : Data Primer

pembungan (disposal) (Galileo, 2012). Konsep pengelolaan sampah yang dilakukan di Kota Yogyakarta telah sesuai dengan SNI 192454-2002 tentang tata cara teknik operasional pengelolaan sampah perkotaan yaitu meliputi pemilahan, pengumpulan, pemindahan, pengangkutan, dan tempat pembuangan akhir (BSN, 2008).

Manajemen pengelolaan sampah di perkotaan merupakan kewajiban pelay- anan publik pemerintah daerah. Pengelolaan sampah perkotaan membutuhkan sumber daya yang sangat besar karena timbulan sampah yang tidak pernah berkurang dan dampak besar yang ditimbulkan terhadap kesehatan dan kerusakan lingkungan. Hal ini sesuai dengan konsep yang dikembangkan di WHO bahwa manajemen pengelolaan sampah merupakan tanggung jawab setiap negara. Pengelolaan sampah harus berorientasi kepada kesehatan, 
Tabel 4. Kerja Sama Lintas Sektoran Pengelolaan Sampah di Kota Yogyakarta

\begin{tabular}{|c|c|c|c|}
\hline No & Instansi & Deklarasi kerja sama lintas sektoral & Dokumen \\
\hline 1 & $\begin{array}{l}\text { Sekertariat bersa- } \\
\text { ma Kartamantul, } \\
\text { DPUP-ESDM, } \\
\text { BLH Sleman, } \\
\text { Bantul, dan Kota } \\
\text { Yogyakarta }\end{array}$ & $\begin{array}{l}\text { Rapat Koordinasi tanggal } 29 \text { November } 2013 \text { yang di- } \\
\text { hadiri oleh sekertaris daerah DIY, Kabupaten Sleman, } \\
\text { Bantuul, dan Kota Yogyakarta. Pembahasan tentang ke- } \\
\text { bijakan kerja sama pengelolaan TPA Piyungan dengan } \\
\text { hasil : pengelolaan TPA Piyungan diserahkan kepada } \\
\text { DIY (DPUP-ESDM DIY) dengan bekerja sama kabu- } \\
\text { paten/kota. }\end{array}$ & $\begin{array}{l}\text { Buletin Kartamantul Edisi } \\
\text { IV } 2013\end{array}$ \\
\hline 2 & $\begin{array}{l}\text { PPEJ Regional } \\
\text { Jawa dengan } \\
\text { BLHD }\end{array}$ & $\begin{array}{l}\text { Pusat Pengelolaan Ekoregion Jawa (PPE Jawa) dengan } \\
\text { Badan/Kantor Lingkungan Hidup di daerah (BLHD) wa- } \\
\text { laupun tidak memiliki hubungan yang bersifat struktural } \\
\text { namun memiliki hubungan yang bersifat fungsional sub- } \\
\text { stantif. Dalam hal ini, PPE Jawa merupakan jawaban atas } \\
\text { prinsip dasar pengelolaan lingkungan hidup yang tidak } \\
\text { dapat dibatasi berdasarkan wilayah administratif, sekali- } \\
\text { gus sebagai perwujudan dari mandat yang diberikan oleh } \\
\text { Undang-Undang Nomor } 32 \text { Tahun } 2009 \text { tentang Perlind- } \\
\text { ungan dan Pengelolaan Lingkungan Hidup. }\end{array}$ & $\begin{array}{l}\text { Rumusan Hasil Rapat } \\
\text { Koordinasi Perlindungan } \\
\text { dan Pengelolaan Ling- } \\
\text { kungan Hidup (RAKOR- } \\
\text { PPLH) Ekoregion Jawa } \\
\text { Tahun 2014 Yogyakarta, 17 } \\
\text { Juni } 2014 \text { (http://ppejawa. } \\
\text { com/46 rumusan ra- } \\
\text { koreg 2014.html) }\end{array}$ \\
\hline
\end{tabular}

Sumber : Data Primer

pembiayaan yang efektif, dan berorientasi pada kebijakan `sarana dan sarana umum merupakan tanggung jawab pemerintah karena menyangkut hajat hidup orang banyak, baik untuk memenuhi kebutuhan pokok sehari-hari maupun kebutuhan sekunder. Tanggung jawab tersebut menyangkut penyediaan dan pengaturan dalam pengelolaan prasarana dan sarana. Di sisi lain upaya pengelolaan sampah membutuhkan koordinasi di antara beberapa instansi terkait (Riduan, 2012).

Walaupun begitu masyarakat masih banyak yang mengharapkan pengelolaan sampah ditangani oleh pemerintah. Masyarakat lebih memilih untuk membayar retribusi kebersihan dibandingkan dengan kerepotan mengelola sampah sendiri. Hal tersebut sesuai dengan penelitian bahwa dari sebagian responden di Kota Makasar mengharapkan pemerintah mengambil tanggung jawab penuh untuk mengelola sampah domestik, dan masyarakat hanya diwajibkan untuk membayar retribusi (Dilla, 2007).

Kebijakan pengelolaan sampah di Kota Yogyakarta meliputi peraturan perundangan dan regulasi tentang persampahan yang mengikat dan diberlakukan di Kota Yogyakarta, serta kebijakan pimpinan instansi pemerintah yang menghasilkan program kerja pengelolaan sampah. Kebijakan yang ditetapkan dalam peraturan perundangan dan regulasi akan lebih mengikat warga masyarakat. Hal tersebut disebabkan karena dalam peraturan perundangan dan regulasi ada hak dan kewajiban serta hukuman bagi yang melanggar. Hal tesebut memastikan agar tidak terjadi pelanggaran. Kewajiban akan memaksa masyarakat untuk menjalankan apa yang menjadi tugasnya dan hak akan memastikan masyarakat mendapatkan pelayanan yang baik dari pemerintah.

Pengelolaan persampahan suatu daerah sangat ditentukan oleh peraturan yang mendukungnya. Peraturan tersebut melibatkan wewenang dan tanggung jawab pengelola kebersihan serta partisipasi masyarakat dalam menjaga kebersihan dan pembayaran retribusi. Macam-macam peraturan daerah yang merupakan dasar hukum bagi pengelolaan persampahan adalah peraturan daerah yang dikaitkan dengan ketentuan umum pengelolaan kebersihan yang ditujukan bagi masyarakat, peraturan daerah mengenai pembentukan institusi formal, dan peraturan daerah yang menentukan struktur tarif dan tarif dasar pengelolaan kebersihan (Rizal, 2011).

Peraturan perundangan dan kebijakan terkait dengan manajemen persampahan di Kota Yogyakarta diantaranya berbentuk retribusi bagi rumah tangga ataupun instansi yang membuang sampah. Peraturan dan kebijakan diperlukan dalam mendukung kesuksesan manajemen pengelolaan sampah karena akan diikuti dengan penegakan hukum yang memaksa masyarakat (Tukahirwa, 2010).

Pelayanan persampahan yang diberikan BLH Kota Yogyakarta didukung retribusi sampah walaupun masih dibutuhkan banyak subsidi dari APBD. Penerapan biaya retribusi disesuaikan dengan volume sampah yang dibuang dan jumlah keluarga. Penetapan biaya berdasarkan berat tersebut idealnya dapat 
membuat masyarakat berfikir untuk menambah produksi sampah, karena semakin banyak sampah yang dihasilkan maka semakin besar retribusi yang harus dibayarkan. Kerja sama lintas sektoral dalam pengelolaan sampah telah dilakukan antara PPEJ Regional Jawa, DPUPESDM DIY, Sekber Kartamantul, dan Badan Lingkungan Hidup Kota Yogyakarta. Kerja sama lintas sektoral yang dilakukan salah satunya untuk melakukan pengelolaan sampah perkotaan dan operasional TPA Piyungan. Berbagai bentuk tanggung jawab dalam mengelola sampah yang memungkinkan telah dilakukan sesuai kapasitas masing-masing.

Hal tersebut juga sesuai dengan penelitian yang dilakukan di kota Semarang, bahwa penanganan sampah domestik umumnya ditangani oleh Dinas Kebersihan dan Pertamanan yang membawahi Unit Pelaksana Teknis Daerah (UPTD) Tempat Pemprosesan Akhir (TPA), TPA berada di Kelurahan Jatibarang sebagai pusat pengolahan dan pemrosesan sampah Kota Semarang, Badan Lingkungan Hidup (BLH) dan Dinas Pasar yang membawahi sampah di pasar-pasar (Ernawati, 2012).

Kerja sama pengelolaan sampah juga dilakukan di Bali dengan membentuk Sarbagita. Sarbagita adalah suatu ikatan kerjasama wilayah yang terdiri dari Kota Denpasar, Kabupaten Badung, Kabupaten Tabanan dan Kabupaten Gianyar dalam rangka memecahkan berbagai permasalahan pengelolaan lingkungan hidup dan kebersihan secara terpadu terutama untuk mewujudkan kepentingan bersama di wilayah Sarbagita (Anggraini, 2011). Peran pemerintah dalam pengelolaan sampah terpadu di memang sangat penting, namun keterlibatan seluruh stakeholders dalam pengelolaan sampah terpadu akan menjadikan segala sesuatunya menjadi lebih efektif dan efisien (Aditya, 2010). Kerja sama dengan stakeholder sangat dibutuhkan. Penanggulangan sampah membutuhkan kerja sama antara pemerintah pusat dan daerah, sektor swasta, nasional dan internasional LSM, nasional dan internasional investor, dan masyarakat (Moruff, 2012). Untuk dapat berhasil dalam mengelola sampah perkotaan dibutuhkan kerja sama antar sektor informal dan sektor formal (Ojo, 2014).

Hasil kerja sama lintas sektoral baru terkait teknis pengelolaan sampah. Penelitian ini menemukan tidak didapatkan adanya kerja sama atau koordinasi lintas sektoral dengan dinas kesehatan. Padahal dampak besar yang pasti timbul dari pengelolaan sampah perkotaan adalah dampak kesehatan selain dari dampak kerusakan lingkungan. Belum ditemukannya fakta tentang kerja sama secara terstruktur antara pelaksana teknis pengelolaan sampah perkotaan dengan dinas kesehatan setempat juga ditemukan di Kota Semarang (Ernawati, 2012). Tidak adanya kerja sama antara dinas pengelola sampah dengan dinas kesehatan juga ditemukan di Bali (Anggraini, 2011).

\section{Penutup}

Permasalahan persampahan Kota Yogyakarta meliputi permasalahan di bagian hilir, yaitu penimbul sampah (masyarakat) yang terus meningkat. Permasalahan di bagian proses, yaitu organisasi pengelola sampah Kota Yogyakarta (BLH Kota Yogyakarta) disebabkan karena keterbatasan sumber daya dan anggaran. Permasalahan di bagian hulu, yaitu pada pengelola sampah akhir (TPA Piyungan) yang disebabkan karena sistem atau teknologi yang diterapkan belum optimal.

Permasalahan persampahan Kota Yogyakarta diselesaikan dengan membuat kebijakan pengelolaan sampah,menjalankan kewenangan dan kapasitas dalam mengelola sampah secara optimal, serta dilakukan kerja sama lintas sektoral. Kerja sama lintas sektoral yang dilakukan belum meliputi bidang kesehatan.

\section{Daftar Pustaka}

Aditya. Sarwono. Rozikin. 2010. Sinergitas Stakeholders Untuk Administrasi Publik Yang Demokratis Dalam Perspektif Teori Governance (Studi Pada Tempat Pengelolaan Sampah Terpadu Mulyoagung Bersatu Kecamatan Dau, Kabupaten Malang). Jurnal Administrasi Publik, 2 (3) : 407-413.

Anggraini. 2011. Aspek Kelembagaan Pada Pengelolaan Tempat Pemrosesan Akhir Sampah Regional. Jurnal Permukiman, 6 (2) : 65-74.

BSN. 2008. SNI tentang Pengelolaan Sampah di Pumukiman, SNI 3242 : 2008. Badan Standarisasi Nasional. Indonesia.

Burhanudin. Budiyono. Mulasari, S.A. 2008, FaktorFaktor yang Berhubungan dengan Kelainan Kulit Secara Subjektif Petugas Pengakut Sampah Di Kota Yogyakarta. Jurnal Kesmas, 
2 (1) : 43-53.

Butu, A.W. Mshelia. 2014. Municipal Solid Waste Disporsal and Environmental Issue in Kano Metroolis, Nigeria. British Journal of Environmental Sciences, 2 (2) :10-26.

Chikobnu, D. Makarati, F. 2011. The Challenges of Solid Waste Disporsal in Rapidly Urbanizing Cities : A Case of Highfield Suburb in Harare, Zimbabwe. Journal of Suistainable Development in Africa, 13 (7) : 184-199.

Dilla, M., Natsir, M.T., Onesinus. 2007. Baseline Service of Community and Cleaning Agency For Municipal Solid Waste Management in Makasar of South Sulawesi. Journal of Applied Sciences in Enveronmental Sanitation, 2 (2) : 63-66.

Ernawati, Budiastuti, Masykuri. 2012, Analisis Komposisi, Jumlah Dan Pengembangan Strategi Pengelolaan Sampah Di Wilayah Pemerintah Kota Semarang Berbasis Analisis SWOT, Jurnal Ekosains, 4 (2) : 13-22.

Fafioye, O.O. John-Dewole. 2013. A-Critical Assessment of Waste Management Problems in Ibadan South-West Local Government Area, Ibadan, Nigeria. Greener Journal of Environmental and Management Studies, 2 (2) : 066064.

Galileo, R. 2012. Kebijakan Pemerintah Daerah Dalam Pengelolaan Sampah Pasca Penetapan UU No. 18 Tahun 2008. Jurnal Demokrasi \& Otonomi Daerah, 10 (1) : 1-66.

Hai, F.I. Ali, M.A. 2005. A Study on Solid Waste Management System of Dhaka City Corporation : Effect of Composting and Landfill Location. UAP Journal of Civil and Environtmental Engeenering. 1 (1):18-26.

Kosmanto, Y., Rohidin, Brata, B. 2012. Strategi Pengelolaan Sampah di Tempat Pembuangan Akhir (TPA) Kabupaten Bengkulu Selatan Tahun 2012. Naturalis Jurnal Penelitian Pengelolaan Sumberdaya Alam dan Lingkungan. 1 (1): 7-14.

Moruff, M. 2012. Cultural Understanding of Space and Waste Disporsal Habit among The Urban Populace in Ibadan Metropolis, South Western Nigaria, Journal of Sustainable Development in Africa, 14 (4) : 82-95.

Mulasari, S.A. 2007. The Community Participation Factor of Waste Self-Management in Gondolayu Village Province of Yogyakarta. Pro- ceedings International Seminar on Reserch in Sciences. Ahmad Dahlan University Yogyakarta, Indonesia. September 11th 2007 : 224-232.

Mulasari, S.A., Sulistyawati, 2014. Keberadaan TPS Legal dan TPS Ilegal di Kecamatan Godean Kabupaten Sleman. Jurnal Kemas. 9 (2) : 122-130.

Ojo, G.O., Bowen, D.M. 2014. Environmental and Economic Analysis of solid Waste Management Altirnatives For Logos Municipality Nigeria, Journal of Sustainable Development in Africa, 16 (1) : 113-144.

Riduan, A. 2012. Partisipasi Masyarakat Dalam Pengelolaan Sampah di Bantaran Sungai Ksli Nagara Kabupaten Hulu Sungai Utara. Jurnal Socioscientia, 4 (2) : 187-196.

Rizal, M. 2011. Analisis Pengelolaan Persampahan Perkotaan (Studi Kasus pada Kelurahan Boya Kecamaan Banawa Kabupaten Danggola). Jurnal SMARTek, 9 (2) : 155-172.

Sharholy, M. et al. 2008. Municipal Solid Waste Managemen in Indian City - A Rewiew. Waste Management, 28 : 459-467.

Suharto, E. 2008. Penerapan Kebijakan Pelayanan Publik bagi Masyarakat dengan Kebutuhan Khusus : Pengalaman Departemen Sosial, Focus Group Discussion : Kajian Penerapan Pelayanan Khusus (Service for Customer with Special Needs) pada Sektor Pelayanan Publik, Lembaga Admionistrasi Negara, Sahira Butik Hotel, Oktober, Bogor.

Suyanto, E. et al. 2014. Analysis on Local Wishdom Based Green Community Participation Suporting The Developmental Program at The Green City Purwokerto Indonesia (A Case Study of Household Waste Management). International Journal of Research in Earth \& Enviromnment Sciencies, 2 (5) : 1-9.

Tukahirwa, J.T. Mol, A.P.J. Oosterveer, P. 2010. Civil Society Participation in Urban Sanitation and Solid Waste Management in Uganda. Local Environment, 15 (1) : 1-14.

Yin, R.K. 2014. Studi Kasus Desain dan Metode. Cetakan Kelima. Devisi Buku Perguruan Tinggi. PT RajaGrafindo Persada. Jakarta.

Zeng, Y. et al. 2005. Characterization of solid Waste disposed at Colombia Sanitary Landfill in Mussouri. Journal Waste Management \& Research, $23: 62-71$. 